\title{
Research Organizations in British Shipbuilding and Large Marine Engine Manufacture: 1900-1945 (Part I)
}

\section{Hugh Murphy}

Cet article est le premier d'une série de trois sur les organismes de recherche en construction navale britannique et en fabrication de gros moteurs marins (diésel et à turbine). Dans cette première partie, qui traite de la période 1900-1945, l'auteur analyse les antécédents et la création ultérieure de deux associations de recherche propres à l'industrie, soit la British Shipbuilding Research Association et la Parsons Marine Turbine Research and Development Association, toutes deux créées en 1944. Il traite également de William Doxford \& Sons, le premier fabricant britannique de moteurs diésel marins à faible vitesse établi sur la rivière Wear à Sunderland et, tangentiellement, du National Physical Laboratory, une institution financée par l'État, et sa division des navires.

\section{Introduction}

Research may be described as scientific investigation with the purpose of discovering new facts by theory or by experiment. ${ }^{1}$ Immediate results are not always apparent, and, in industrial research, start-up costs are usually high, especially if no comparable function exists on a firm-by-firm or industry basis. For pragmatic and practical reasons, research directed towards practical ends, resulting in recognizable gains in output and efficiency is normally the goal. Moreover, it is an obvious point, but one nevertheless worth stating that firm-specific research, by its nature, primarily tends to benefit the firm, at least in its initial stages, and not an industry.

1 I thank the anonymous referees for their comments.

The Northern Mariner / Le marin du nord, XXX, No. 1 (Spring 2020), 1-22 
By 1943, the latter point had somewhat tardily dawned upon representatives of British shipbuilders and marine engineers. Not only was at it by this stage generally accepted that the old system of firm-specific research was costly and generally involved some duplication of effort, it was also felt that the time was opportune to create two new research associations for the British shipbuilding and marine engine building industries, the British Shipbuilding Research Association (BSRA), and the Parsons Marine Turbine Research and Development Association (PAMETRADA) both of which were formed in $1944 .^{2}$

Given this, the rationale for this three-part article is simply stated: generally, industry-specific research as a topic remains under-researched in maritime history, and this is particularly the case for the twentieth century regarding the British shipbuilding and large slow speed marine diesel engine-building and steam turbine industries. One can of course look to engineering textbooks, the trade press $^{3}$ and to the transactions of learned institutions to gain some understanding of technical progress on a product or process over time. This implies at least the desire to gain, perhaps with some prior knowledge of scientific principles underpinning initial and subsequent development, an understanding of how innovation occurs, leading to development, diffusion and assimilation of a specific product or process.

For the purposes of this article however, overtly technical descriptions are eschewed as it is primarily written for a non-technical readership. Specifically, I analyse in Part I, which covers the period 1900-1945, the antecedents to, and subsequent creation of two industry-specific research associations, BSRA and PAMETRADA, and Great Britain's premier slow speed marine main diesel engine manufacturer Wm. Doxford \& Sons at Sunderland on the River Wear, and tangentially, one state-funded institution, the National Physical Laboratory and its Ship Division. In Part II to follow, which covers the period 1946-1959, I consider BSRA and PAMETRADA's impact, and one private research consultancy cluster, the Yarrow Admiralty Research Department (YARD) an offshoot of Yarrow Shipbuilders, Scotstoun, on the Upper Clyde, and, in greater depth, Wm Doxford \& Sons before assessing their individual and collective impact up to 1959. Finally, Part III covers the period 1960-1977, when the vast majority of the British shipbuilding and large marine engine manufacturing firms were nationalised under British Shipbuilders Plc, I consider the publication of three landmark governmentsponsored reports on British shipbuilding and marine engine manufacture, (DSIR, 1960), (SIC 1965-1966) and (Booz, Allen and Hamilton, 1973). ${ }^{4}$ I also consider one

\footnotetext{
2 Shipbuilding Conference Executive Board Reports, January to April 1943, National Maritime Museum, Greenwich, Shipbuilders and Repairers National Association Papers (SRNA).

3 Of value to researchers of the British shipbuilding and marine engine building industries are: Engineer (from 1856), Fairplay (from 1883), The Shipbuilder (from 1906), the Liverpool-based Journal of Commerce and Shipping Telegraph (from 1911), Shipbuilding and Shipping Record (from 1913), The Motor Ship (from 1925), and The Shipbuilder and Marine Engine Builder (from 1946).

4 United Kingdom, Department of Scientific and Industrial Research, Research and Development Requirements of the Shipbuilding Industries (London, HMSO, 1960), hereafter DSIR Report; Report of the Shipbuilding Inquiry Committee 1965-1966 (London: HMSO, 1966), hereafter SIC Report;
} 
shipbuilding industry report of 1962 on productivity, ${ }^{5}$ and conclude by assessing the impacts of BSRA, PAMETRADA, Doxford, YARD and the NPL on British shipbuilding and main marine engine manufacturing generally to 1977.

\section{The antecedents to BSRA and PAMETRADA}

\section{Industrial Research relevant to shipbuilding in Britain prior to 1945}

In July 1898 a committee of inquiry under Lord Rayleigh (1842-1919), ${ }^{6}$ appointed by the Treasury the previous year, recommended the establishment of a National Physical Laboratory (NPL) under the control of the Royal Society. Its remit was "for standardising and verifying instruments, for testing materials and for the determination of physical constants." " First established at Kew Observatory on New Year's Day 1900, the Royal Society appointed Richard Tetley Glazebrook (18541935), its first director. The NPL was formally opened in new accommodation by HRH The Prince of Wales at Teddington, Middlesex on 19 March 1902. He remarked that he believed that it was the first instance of the state taking part in industrial research. ${ }^{8}$ The Royal Society controlled the laboratory through a general board and an executive committee of sixteen members, grant aid being provided by the Treasury.

By 1908, the NPL Ship Division had been formed to study the hydrodynamic performance of ships, principally by means of experiments with models through design studies commissioned by shipbuilders and ship owners. Consequently, by September 1910, through the generosity of the Clyde shipbuilder, Sir Alfred Yarrow (1842-1932), ${ }^{9}$ a ship model testing tank (National Experimental Tank) had been completed and filled. ${ }^{10}$ It was officially opened by Lord Rayleigh on 5 July 1911. The tank was $150 \mathrm{~m}$ by $9 \mathrm{~m}$ wide and held 5000 tonnes of water with a centre depth of $3.75 \mathrm{~m} .{ }^{11}$ The perceived success of ship model tanks in Great Britain led to a spate of model test tanks being built abroad before the advent of the Great War, often with a military purpose, in Italy, France, Germany, Japan, the Netherlands,

\footnotetext{
Booz, Allen and Hamilton International BV British Shipbuilding 1972: A Report to the Department of Trade and Industry (London: HMSO, 1973).

5 Productivity and Research in Shipbuilding: Report of the Main Committee under the chairmanship of Mr James Patton to the Joint Industry Committee, March 1962.

6 John William Strutt, $3^{\text {rd }}$ Baron Rayleigh was an eminent physicist, who, with John Ramsay, discovered Argon, for which he was awarded the Nobel Prize for Physics in 1904.

7 For Rayleigh, see, H. Barrell, "The Rayleighs and the National Physical Laboratory," Applied Optics 3:10 (1964), 1125-1128.

8 http:www.npl.co.uk History, and NPL Annual Reports, various years.

9 Yarrow had decamped from Cubitt Town on the River Thames to a new shipyard at Scotstoun on the Upper Clyde, completing a torpedo boat destroyer there in July 1908. For Yarrow, who was created a baronet in 1916, see Lady Yarrow, Alfred Yarrow: His Life and Work, (London: Edward Arnold and Co., 1923). Yarrow contributed $£ 20,000$ to build the National Tank at the NPL, Teddington.

10 Later the William Froude Experimental Tank and thereafter, No.1 Ship Tank.

11 http:www.npl.co.uk History.
} 
Russia and the United States. ${ }^{12}$

Prior to the outbreak of the First World War, there were a small number of state organizations such as the NPL with a specialised scientific interest, but there was no real effort made to co-ordinate effort towards application and diffusion of discoveries made in research, and no organisation concerned with the application of science to industry. The creation of such an organization was given added impetus by the needs of the war effort, which "proved how dependent the country was on enemy industries for products essential to its defence."13

By May 1915, a white paper on the establishment of a permanent organisation for the promotion of scientific and industrial research was presented to Parliament, ${ }^{14}$ and by an order in council of 28 July 1915 authority for such an organisation was vested in a committee of the Privy Council to oversee public monies voted by parliament to be allocated to industry for research and development (R\&D) purposes. This committee was substantially aided in its deliberations by a small advisory council whose primary tasks were to promote the scientific study of the problems of various industries and to advise on specific research projects. As a first step, a scheme was devised for encouraging groups of firms to set up co-operative industrial research associations. For this purpose, a lump sum of $£ 1 \mathrm{~m}$, the "Million Fund, was voted and an imperial trust was set up to administer it. ${ }^{15}$

The executive action needed to implement the recommendations of the advisory committee was placed with the newly formed Department of Scientific and Industrial Research (DSIR), responsible to Parliament through the Lord President of the Council. ${ }^{16}$ Thereafter, with DSIR support and financial aid in the

12 Italy, La Spezia in 1889; France, Grenelle, Paris in 1906; Germany, Uibigau, Dresden in 1892, Bremerhaven, 1900, Charlottenburg, Berlin in 1903; Japan, Nagasaki in1908; The Netherlands, Amsterdam in 1876; Russia, St Petersburg in 1893; United States, Washington D.C. in 1898. The first commercial but smaller experimental model ship testing tank built by Denny in Dumbarton was opened in 1883 to test scale models to determine the most efficient hull form and power requirements for any vessel. The facility was enhanced with the installation of a wave making machine in 1887 to simulate rough seas during testing. Earlier, William Froude had begun his investigations with ships' models at an experimental tank at Torquay about 1871, carrying it on uninterruptedly until his death in 1879 . Thereafter, his work was carried on by his son, Mr. R. E. Froude. At the beginning of 1886, the experimental appliances and effects were removed from Torquay to Haslar, Gosport, near Portsmouth, where a larger model ship testing tank and offices were constructed to encourage greater experimental investigation. The proximity of the Haslar tank to the Admiralty dockyard at Portsmouth enabled the Royal Navy to make more frequent use of it than was hitherto the case. See, A.T. Chrichton, "William and Robert Edmund Froude and the Evolution of the Ship-Model Experimental Tank," Transactions of the Newcomen Society, 61 (1989-90), and D.I. Moor, "Ship Model Experiment Tanks; The First Century. A British View," Transactions of the North East Coast Institution of Engineers and Shipbuilders, 101, (1984).

13 Sir H. Frank Heath GBE, KCB and A.L. Hetherington CBE, Industrial Research and Development in the United Kingdom. A Survey, (London: Faber and Faber, 1946), 250, this was particularly apt in chemicals and dyestuffs.

14 British Parliamentary Papers Cmd 8005, Scheme for the Organisation and Development of Scientific and Industrial Research (London: HMSO, 1915).

15 For a fuller description of this process, see, Heath and Hetherington, chapters 31 and 32.

16 The records of the DSIR and the Imperial Trust are held in the DSIR 15 and 16 classifications at 
form of annual grants proportionate to the income from subscriptions from member firms, numerous co-operative industrial research associations were formed, which included those serving the coal, iron and steel industries.

DSIR support was given to associations representing the major proportion of firms in an industry and having the declared object of the prosecution of research based on scientific principles to be made available to all members of the association. Each association was in effect a self-governing body and was singularly responsible for drawing up its own programme of long-term research, which, in addition to investigations with more immediate objectives likely to provide early answers to industry specific problems, would also, it was hoped, improve the prospects of the industry concerned. With DSIR aid there grew up a swathe of research associations in British industry with research undertaken in the broad network of associations clearly seen as in the national interest. ${ }^{17}$

\section{National Physical Laboratory}

By 1918 the NPL was firmly established in its twin functions as a laboratory of industrial research, and a national testing institution or proving house. ${ }^{18}$ It was hoped that under the new aegis of the Imperial Trust for the Encouragement of Scientific and Industrial Research the sphere of usefulness of the NPL would be still further enlarged, and that, with the extension of its scope, shipbuilders would take fuller advantages of the National Tank testing facilities at Teddington. ${ }^{19}$ In time, the NPL became the UK's national standards laboratory and the focus of the National Measurement System, and also provided standards and precision methods of measurement over a wide range of physical quantities for industry, government and universities.

In its report of 1917, the DSIR entertained the rather pious hope that cooperative research associations would be self-funding after the initial five-year funding cycle. ${ }^{20}$ The department was in time disabused of this hope, as by 1923 only one research association, Portland Cement, could continue through independent funding. DSIR continued to fund the remaining associations for a further five years, and continued to do so after 1928, as by this stage it was evident that most would collapse if not in receipt of state funding. ${ }^{21}$ The Balfour Committee on Industry and

\footnotetext{
the National Archives, Kew, London (hereafter, TNA DSIR). See, TNA DSIR 15/1 Constitution and Functions.

17 TNA DSIR 15/1 and 16/1. Among the swathe of organizations were the British Cotton Industry Research Association (RA), the British Boot and Shoe and Allied Trades RA, the British Linen Industry RA, the British Portland Cement RA, the British Electrical and Allied Industries RA, the British Cast Iron Industry RA and the British Photographic RA. However, not all RAs funded lasted beyond the 1930s depression, two examples are British Cutlery RA and the British Motorcycle and Cycle Car RA which were both wound up in 1932. See TNA DSIR 16/60 and TNA DSIR 16/96.

18 Shipbuilding and Shipping Record, 7 March 1918.

19 Ibid.

20 DSIR Report, 1917, 49.

21 D. C. Mowery, "Industrial Research, 1900-1950," in B. Elbaum \& W. Lazonick, eds., The
} 


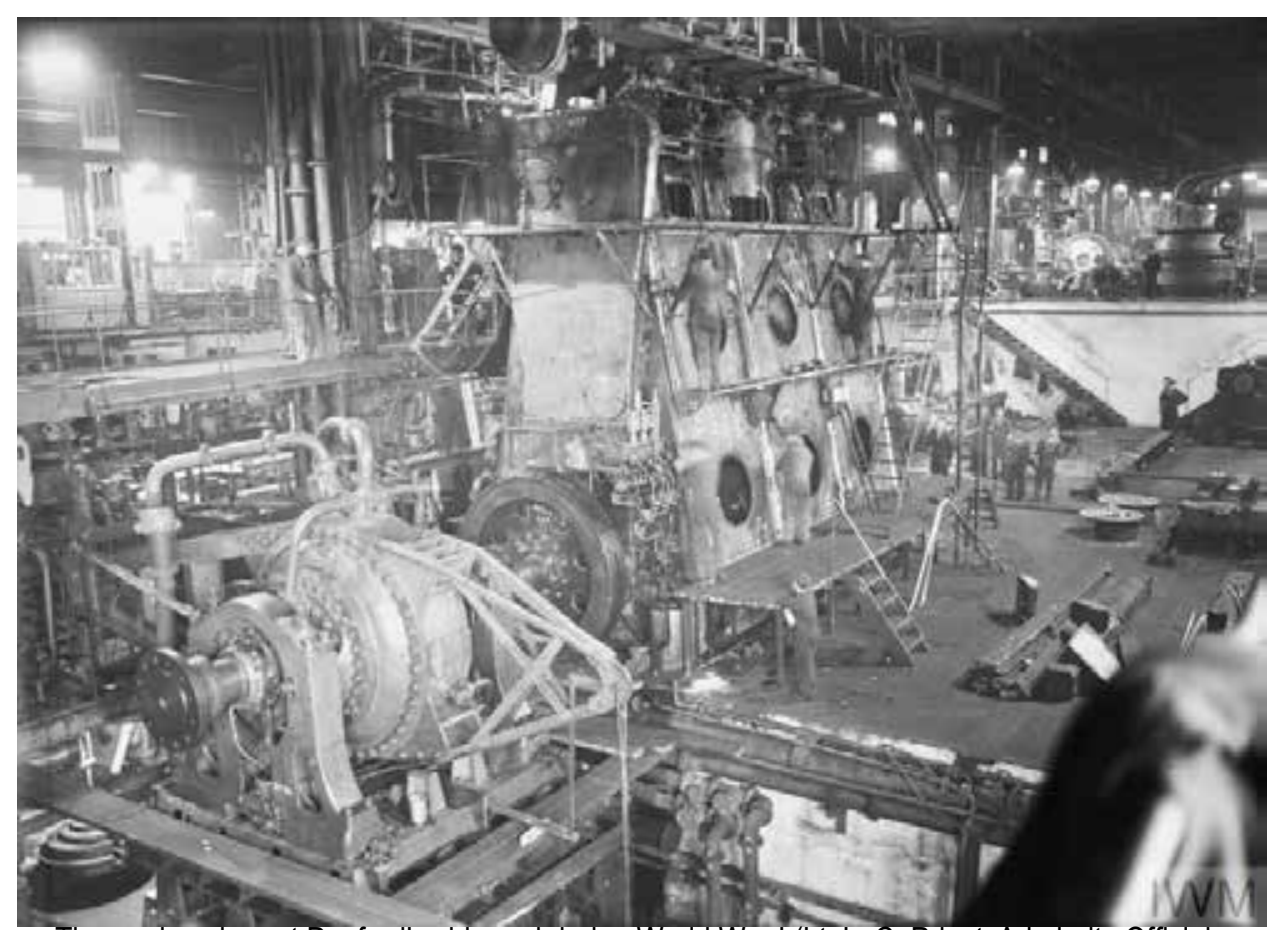

The engine shop at Doxford's shipyard during World War I (Lt. L. C. Priest, Admiralty Official

Collection, Imperial War Museum, A 5307)

Trade set up in 1924, which produced a final report in $1929,{ }^{22}$ remarked upon the lack of dissemination of the results of research associations' research to member firms. Hill noted that the average expenditure of research associations at the nadir of the interwar depression in 1933 was a paltry $£ 14,500$ per annum. ${ }^{23}$ Moreover, in the wider British economy by 1936, only twenty of the top two hundred firms had research facilities. ${ }^{24}$

How far the existence of research associations contributed to economic growth remains unclear when studying British industry. Edgerton and Horrocks, who do not discuss shipbuilding or marine engine building in a 1994 article, noted that prior to 1945: "British industry funded and performed R\&D to a much greater extent than historians had hitherto appreciated." Moreover, there was an overwhelming importance of in-house $R \& D$, but this was concentrated on a few

Decline of the British Economy (Oxford: OUP,1986), 206.

22 British Parliamentary Papers Cmd 3282, 1928-9, Final Report of the Balfour Committee on Industry and Trade. Chaired by the industrialist Arthur Balfour (1873-1957), the committee produced six volumes of material. Its initial purpose was to enquire into the conditions and prospects of British industry and commerce, and of factors making for industrial and commercial efficiency.

23 D.W. Hill, Co-operative Research in Industry, (London: Hutchinson's Scientific and Technical Publications, 1947), 45.

24 Mowery, "Industrial Research," 192. Mowery also notes that in 1933, 116 of the firms in a sample of 160 from the top 200 US firms had research laboratories. 
sectors, particularly chemicals and chemistry thereon. ${ }^{25}$ In this, Edgerton and Horrocks were critical of post hoc declinist explanations, in part advanced through failings in R\&D. ${ }^{26}$ In house research, albeit fragmented, undoubtedly continued during the interwar period, but the extent of British shipbuilding and larger marine engine building firms R\&D efforts were mostly conditioned by the largely grim economic situation, which confronted them.

\section{The British shipbuilding and large marine engine building industries}

\section{Shipbuilding}

Prior to the Great War, British shipbuilding firms dominated world output in mercantile and naval construction. By the interwar period, British shipbuilding could be described as a mature assembly industry and one which remained largely wedded to bespoke riveted construction for mainly British owners. Moreover, universal principles in hull forms, propulsion systems and auxiliary equipment had long been understood with ships mostly designed by specialists trained in naval architecture. The bulk of applied research in shipbuilding that had been undertaken, notwithstanding the considerable bulk of Admiralty research related to warships ${ }^{27}$ had been of an ad hoc nature. Whilst the volume of research undertaken in private establishments had resulted in improved hydrodynamics (aided by several ship model test tanks in private shipyards), and in improved propulsion systems, research and development generally mirrored the industry's structure, and remained atomistic.

Historically, British shipbuilding firms largely built to order for British owners with the domestic market accounting for 75 to 80 percent of total output. This

\footnotetext{
25 D.E.H. Edgerton and S. Horrocks, "British Industrial Research and Development before 1945," Economic History Review, 47: 2, (1994), 213-238, at 213.

26 In this they were supportive of a much earlier lesser-known article, see, M. Sanderson, "Research and the Firm in British Industry, 1919-1939," Science Studies 2 (1972),114-138, but rejected the assertion of Mowery that British industry had relied heavily on state-funded co-operative research associations and that links between academic and industrial research were weak, fragmented and poorly co-ordinated. In terms of shipbuilding, Mowery's claim has more force as it is very doubtful that the shipbuilders would have established a research association were it not for a substantial element of government funding.

27 On hydrodynamics: at the Admiralty Experiment Works, Haslar near Gosport, since 1886. Its work expanded to cover all types of naval vessel, including the submarine.The Admiralty Fuel Experimental Station was established in 1902, at Haslar, to research into the naval use of oil fuel in boilers and was subsequently absorbed into the Admiralty Marine Engineering Establishments. The Admiralty Engineering Laboratory was established in 1917, at the City and Guilds College, South Kensington to develop diesel engines for submarines, it moved to West Drayton in 1920 where it was joined by the laboratory for electrical experiments that had been set up in 1919. They remained as a separate Mechanical Engineering Department and Electrical Engineering Department, testing commercial engines and equipment for naval use, with limited research functions. In 1977, the laboratory was absorbed by the National Gas Turbine Establishment.
} 
reliance on largely bespoke construction, which militated against widespread standardisation of product and ancillary equipment, only partly explains the general lack of innovation in the industry during the interwar period. Naval construction, for the most part a precursor of innovation and highly profitable; had been vastly reduced, not least because of international naval limitation treaties, but also due to a shift in government economic priorities. Given the dire economic consequences arising from the 1929 depression and the enduring recession in world trade thereafter, research was hardly a priority for shipbuilders and marine engine builders, survival was. ${ }^{28}$

\section{Marine Engine-Building ${ }^{29}$}

Just as the British shipbuilding industry had led the world, so too had its interlinked marine engine building sector, clustered around the major shipbuilding areas. This was particularly the case during the age of steam through Scottish innovation in compound, triple and later quadruple expansion marine steam engines all linked to improved boiler configurations, ${ }^{30}$ and through the application of the marine steam turbine of the reaction type for driving propellers directly, pioneered on the Tyne in the 1890s by Charles Algernon Parsons (1854-1931). ${ }^{31}$

28 At the nadir of the depression in 1932-33 Clyde yards launched only $63,757 \mathrm{gt}$ and $53,368 \mathrm{gt}$ respectively, less than 10 percent of tonnage launched in 1913, and in 1933, 39 percent of tonnage launched in Britain, and 11 percent of world tonnage launched. In that year, 75 percent of the insured workforce in Scottish shipbuilding were unemployed. In a distinct business strategy, many yards closed down for extended periods, for the River Wear Yards the average was five years. The longest period of closure was for eight years at Chas. Connell's yard at Scotstoun on the Upper Clyde, before it reopened in 1938. See, L. Johnman and H. Murphy, "An overview of the Economic and Social Effects of the Interwar Depression on Clydeside Shipbuilding Communities," International Journal of Maritime History 18:1 (2006),227-254.

29 There is a dearth of scholarly articles and books on the British Marine Engine-building industry. For an overview, see, L. Johnman and H. Murphy, "The Rationalisation of Slow Speed Marine Diesel Engine Building in the UK, 1912-1990," in D.J. Starkey and H. Murphy, eds., Beyond Shipping and Shipbuilding: Britain's ancillary maritime interests in the twentieth century (Hull: University of Hull Maritime Historical Studies Centre, 2007), 29-64. See also, D. Burrell, "The Low Speed Diesel in British Shipbuilding up to 1945," Transactions of the North East Coast Institution of Engineers and Shipbuilders, 105:1, pt.4, (1988-89), 19-24; Denis Griffiths, "British Marine Industry and the Diesel Engine," The Northern Mariner/Le marin du nord, 7:3 (1997), 11-40. Two books by J.F. Clarke, Building Ships on the North East Coast, 2 vols., (Whitley Bay: The Bewick Press, 1997), and, Power on Land and Sea: 160 years of Industrial Enterprise on Tyneside; A History of R.W. Hawthorn Leslie \& Co.Ltd (Wallsend: Hawthorn Leslie \& Co., 1979), are useful. For a privately published history of Doxford see. P. Richardson, William Doxford \& Sons Ltd. Shipbuilders and Engineers, 1837-1988 (Addington, Kent: Patricia Richardson, 2019). A notable reference book is, C.C. Pounder, Marine Diesel Engines, (London: George Newnes Ltd., 1952, 1964, 1968, 1972). See also, Eng. Capt. Edgar C. Smith, A Short History of Naval and Marine Engineering, (Cambridge: Cambridge University Press, 1938), and D. Griffiths, Marine Low Speed Diesel Engines (London: IME, 2001) and Medium Speed Marine Diesel Engines (London: IME, 1999).

30 For a full consideration of this, see, A. Slaven, The Development of the West of Scotland (London: Rutledge \& Kegan Paul, 1975), 123-133.

31 For Parsons, see, Rollo Appleyard, Charles Parsons: His Life and Works, (London: Constable, 
After the unannounced introduction of his prototype craft, Turbinia at the Spithead Naval Review of $1897,{ }^{32}$ Parsons erected his Turbinia marine turbine engine works at Wallsend, Newcastle-upon-Tyne in the same year. ${ }^{33}$ Subsequently, demand for his turbines ${ }^{34}$ for naval and mercantile usage soon outstripped his ability to supply; hence he licensed their manufacture to his designs elsewhere, but mainly to British shipbuilding and marine engine building firms. ${ }^{35}$

Parsons invention soon interested the Admiralty when great demands were being made for reliability and durability of warships through reductions in weight of machinery and increased speeds. Post the adoption of Parsons turbines in the battleship, HMS Dreadnought in 1905, ${ }^{36}$ steam turbines displaced steam reciprocating machinery in all significant classes of warship in the Royal Navy. Admiralty research, inter alia, covered design, boilers, engineering, and experimental fuels, and there is no doubt that the fruits of that research were of great benefit to the private shipbuilders and marine engine builders, who built most Royal Navy warships during the twentieth century.

Before the Great War the potential for marine purposes of the internal combustion engine was well understood. By 1912, the upper Clyde shipbuilders

1933).

32 Parsons reputation was sealed in history during Queen Victoria's Diamond Jubilee Naval Review in June 1897, where unannounced, Turbinia was propelled at over 30 knots between the lines of the world's warships. This remarkable demonstration of speed led to orders from the Royal Navy for two turbine-powered torpedo boat destroyers, HMS Viper and HMS Cobra, which led to the Royal Navy and other navies to eventually introduce steam turbines as the propulsion system of major warships. 33 Parsons land turbine firm C.A. Parsons had been established at Heaton, Newcastle-upon-Tyne in 1889. From 1897, onwards his land and marine turbine manufacturing plants operated on a split-site basis in Heaton and Wallsend.

${ }^{34}$ At this stage, there were two main types of turbine, reaction and impulse. The essential difference between the two lies in the shape of the turbine blades. In a reaction turbine, the effect is that a drop-in pressure of the steam is divided equally between the fixed and moving blades. In an impulse turbine, almost the entire pressure drop occurs in the fixed blades, normally referred to as nozzles. Reaction type (Parsons) turbines, although efficient, require a large number of stages and tend to be large and heavy. Impulse turbines require fewer stages and are smaller and lighter for a given power, but it is nevertheless difficult to obtain the stage efficiency of the reaction turbine. As the temperature at which steam is supplied-the higher the temperature the higher the efficiency theoretically possiblethen it follows that a great deal of metallurgical research into blade composition was needed, as was blade positioning and vibration in stress testing under differing steam conditions.

35 Although Parsons reaction turbine was the first marine turbine to be extensively applied to ships, a Swedish engineer, Carl Gustaf Patrik de Laval patented his impulse turbine in 1889. Other patents of note for impulse turbines were later taken out by the French engineer Auguste Rateau and the American inventor Charles Curtis. In 1899 a German engineer Dr H. Zoelly patented a combined impulse-reaction turbine.

36 HMS Dreadnought was commissioned in 1906. She had two paired sets of Parsons direct-drive turbines, each of which was housed in a separate engine-room and drove two shafts. The wing shafts were coupled to the high-pressure ahead and astern turbines and the low-pressure turbines to the inner shafts. Her turbines were powered by eighteen Babcock and Wilcox water-tube boilers. The turbines were designed to produce a total of 23,000 shaft horsepower but reached nearly $27,018 \mathrm{shp}$ during trials in October 1906. Dreadnought was designed for 21 knots but reached 21.6 knots during trials. 
and marine engineers, Barclay Curle had built and engined, the latter under licence from Burmeister \& Wain, the first large ocean-going motor-ship to be built in Britain and the second in the world, Jutlandia. ${ }^{37}$ Post 1912, the advantages of the motor-ship such as fuel economy in weight and space over long distances, reduced manpower, increased cargo capacity, and speed and quicker turnarounds when bunkering, were acknowledged. The marked initial disadvantages were the higher prime costs of diesels and maintenance costs of engines, particularly the high cost of lubricating oils; the initially higher price and lesser availability of oil over coal, and the then marked advantage of steam in power to weight ratio over the marine diesel. The likelihood, however, was that over time these disadvantages would be overcome.

\section{Wm. Doxford \& Sons Shipbuilders and Engineers, Sunderland}

During the Great War, through its Swiss-born chief engine designer, Karl Otto Keller (1877-1942), Doxford had begun to design a four-cylinder opposed-piston slow-speed main marine diesel crosshead engine. ${ }^{38}$ However, Admiralty work took priority during the war, although some main engine research and development did take place on what became known as an opposed piston marine oil engine. Doxford's R\&D costs before an engine was finally developed for service were in the region of $£ 100,000$. $^{39}$

By 1921, Doxford had built the motor cargo liner Yngaren for Swedish owners; the engines were their first four cylinder opposed piston arrangement. ${ }^{40}$ Thereafter, Doxford made incremental improvements to their marine engines, ${ }^{41}$ and

\footnotetext{
37 For the East Asiatic Trading Company of Copenhagen. Launched on 11 November 1912, Jutlandia ran on Scottish shale oil. Her sister ship, Selandia, at 6,800 dwt was the first large ocean-going motor driven cargo and passenger liner to be built in the world. She was launched at Burmeister and Wain shipyard in Copenhagen on 4 November 1911. She was 370ft long and was driven by twin screws with a speed of 11 knots. The honour of the first motor driven ship is usually attributed to the smaller Vulcanus of 1,179 dwt, a tanker for the Anglo-Saxon Petroleum Company built by the Netherlands Shipbuilding Company of Amsterdam in 1910 and engined by Werkspoor with a non-reversible four stroke marine diesel. In fact, diesel engines had been at sea in river and coastal craft for some time, and sea-going motor vessels such as the Swan Hunter and Wigham Richardson 1910 built Toiler of 1,659 gross tons intended for use on Canadian canals and lakes, was the first motor ship to cross the Atlantic, (see, "Swans on the Lakes," Ships in Focus Record 12 (1981), 249.

38 Opposed piston engines should not be confused with flat engines, which are horizontally opposed with one piston per cylinder, and have cylinder heads. Some variations of the opposed piston engine designs used a single crankshaft. Doxford engines used a crankshaft at one end of the cylinders and a crosshead for the opposing piston. The crank throws for each end were often unequal giving a shorter motion for the end having the higher reciprocating weight in order to aid balance.

39 Griffiths, "British Marine Industry and the Diesel Engine," 20.

40 Clarke, Building Ships on the Northeast Coast, Part 2, 101, notes that the engine at $£ 160,435$ cost more than the ship's hull. Yngaren's four-cylinder engine ran at $78 \mathrm{rpm}$ (slow speed) and developed 3,000 ihp.

${ }^{41}$ Ibid., 102-103. Such as improved cylinder liners, solid rather than composite cylinder-head forgings, airless injection, spherical combustion chambers, and by 1924 Doxford had produced its first three cylinder opposed piston engine.
} 
successfully engined many more motor ships. Many British shipbuilders and marine engine-builders, rather than choosing to innovate, instead chose to manufacture Doxford engines and Parsons marine turbines under licensing agreements. The world's largest publicly quoted shipbuilders and marine engineers, the Belfast and Clyde-based Harland and Wolff held the main licence for Danish designed and manufactured Burmeister and Wain slow speed main marine diesel engines. ${ }^{42}$ Doxford's main overseas licensee was the tanker builder, Sun Shipbuilding and Dry Dock Company of Chester, Pennsylvania. ${ }^{43}$

During the speculative post-war boom, the Sperling Combine, through the vehicle of the Northumberland Shipbuilding Company of Howdon on Tyne, ${ }^{44}$ and with financial aid and investment in shares of a London merchant bank, Kleinwort, ${ }^{45}$ acquired controlling share interests in several shipyards. These included, by December 1918, the giant Fairfield Shipbuilding and Engineering firm at Govan on the Upper Clyde, ${ }^{46}$ and by February 1919 the then highly profitable familyowned Wm. Doxford, on the River Wear, acquired through a $£ 3 \mathrm{~m}$ debenture issue. ${ }^{47}$ Sperling's next significant purchase was the Belfast shipbuilder and marine engineers, Workman, Clark, in December 1919.48

When the post-war speculative boom turned to dust, Northumberland was in real trouble, and under a welter of accumulated debt through cross financing of its shipbuilding companies and asset stripping, ${ }^{49}$ the Sperling Combine partnership was dissolved on 24 November $1925 .^{50}$ Northumberland Shipbuilding went into

42 Griffiths, "British Marine Industry and the Diesel Engine," 20, notes that Doxford had four British and two overseas licensees by the end of the 1920s. A Doxford licence cost $£ 10,000$ plus a royalty payment of $£ 1$ per hp. Post-1945, Harland \& Wolff also manufactured an opposed-piston main marine engine under licence from Burmeister and Wain, as did their only British sub-licensee, John G. Kincaid of Greenock on the Lower Clyde, however, the design differed from that of Doxford and such differences were probably due to patent law and infringement thereon.

43 Burrell, "The Low Speed Diesel in British Shipbuilding up to 1945," 22.

44 The Northumberland shipyard was laid out at Howdon on Tyne by H.S. Edwards and Sons in 1883. In July 1918, Robert Alfred Workman, with the support of Sperling and Kleinwort had purchased the Northumberland Shipbuilding Company in July 1918 from the Furness interests for $£ 850,000$. With an initial share capital of $£ 500,000$.

45 Kleinwort advanced Sperling's $£ 50,000$ as a deposit on the purchase price of Northumberland Shipbuilding and also bought $£ 350,000$ of its shares. See, J. Wake, Kleinwort Benson: The history of two families in banking (Oxford: OUP, 1997), 239.

46 Minutes of Fairfield Board of Directors Meeting, 9 December 1918; Northumberland owned more than 80 percent of Fairfield shares, and R.A. Workman replaced Sir Alexander Gracie as chairman. Glasgow City Archives, Mitchell Library, Glasgow, UCS 2/1/5.

47 Tyne and Wear Archives (TWA), Newcastle upon Tyne, TWA DX Dox/1/16/1 Doxford's nominal share capital amounted to $£ 805,030$.

48 For Workman, Clark, see, A. Armitage, "Shipbuilding at Belfast, Workman, Clark and Company, 1880-1935," in L.R. Fischer, ed., From Wheel House to Counting House: Essays in Maritime Business History in Honour of Professor Peter Neville Davies (Liverpool: Liverpool University Press, 1992), 97-124.

49 H. Murphy, "An anatomy of speculative failure. The Northumberland Shipbuilding Company Ltd of Howdon-on-Tyne, 1919-1945." The Mariner's Mirror 104:1 (2018), 58-72.

50 The London Gazette, 4 December 1925. 
voluntary receivership in 1926, by which stage; it had deprived Workman, Clark of "practically the entire assets of the company," and in the Bank of England's view, "ruined the financial position of Doxford by denuding it of its liquid assets." 51 A similar fate had been accomplished at Fairfield, which had been stripped "of all the cash it had accumulated in its years of prosperity." 52

In 1933, Doxford had introduced welded fabrication of the superstructures and supporting frames of its opposed piston engines resulting in substantial size and weight reductions. However, cast iron bedplates were still in use until 1936 when fabricated welded construction was extended to include bedplates. By then the two-stroke marine diesel had "virtually eliminated the four-stroke engine from consideration when engines of more than 2000hp were required."53 Doxford's slow-speed opposed piston main engine was now standardized as an economical balanced three-cylinder unit of a relatively low horsepower rating and was fitted in a series of Doxford Economy ships. The first of these, Sutherland, was completed in January 1935 and burned just 6.5 tons of fuel per day at 10 knots speed. At $£ 100,000$ each it was not as cheap as a steam-powered tramp ship but offered much lower operating costs. ${ }^{54}$

Nonetheless, in main diesel engines, the continental competition had caught up post the nadir of the depression in trade in 1933. Of motor ships of 2,000 tons and above in actual service at March 1937, 718 had Danish Burmeister \& Wain engines, ${ }^{55} 241$ had Swiss-built Sulzer engines, ${ }^{56} 201$ had German MAN engines, ${ }^{57}$

\footnotetext{
51 S. Diaper, "The Sperling Combine and the Shipbuilding Industry: Merchant banking and industrial finance in the 1920s," in J.J. Van Helten and Y. Cassis (eds.), Capitalism in a Mature Economy. Financial Transactions, Capital Exports and British Industry, 1870-1939 (Aldershot: Edward Elgar Publisher, 1990), 83.

52 H. Peebles, Warshipbuilding on the Clyde: Naval Orders and the Prosperity of the Clyde Shipbuilding Industry, 1889-1939, (Edinburgh: John Donald Publishers, 1987), 127.

53 I. McNeil (ed.), An Encyclopaedia of the History of Technology, (London: Routledge, 1990), 324.

54 R. Fenton, Tramp Ships. An Illustrated History (Barnsley: Seaforth Publishing, 2013 ), 88.

55 Burmeister \& Wain acquired the rights of the Diesel patent in 1898 and provided the four stroke marine diesels for the pioneering trio of large motor ships Selandia, Jutlandia (manufactured under licence) and Fionia of 1912. J. Lehmann, A Century of Burmeister \& Wain, (Copenhagen: Burmeister \& Wain, 1948), and J. Pedersen, Teknologisk udvikling i maskinindustrien. Burmeister \& Wain, 18751939 (Copenhagen: Burmeister \& Wain, 1999) By 1930, B\&W offered two stroke marine diesels. 56 Sulzer Brothers of Winterthur, Switzerland had purchased certain rights to diesel engines in 1903 began manufacturing marine diesel engines. In 1911 they produced a much larger version of their 1905 engine ushering in the era of the two-stroke slow speed marine main diesel engine. In 1914 the family firm was transformed into three joint-stock companies, one of which was based in Germany and the other a holding company. Sulzer had licensees in Great Britain, Belgium, France, Germany, Italy, Japan, the Netherlands and the USA. See, D.T. Brown, A History of the Low Speed Marine Diesel Engine (Winterthur: Sulzer, 1984).

57 MAN were the pioneers of the diesel engine and they and their licensees manufactured submarine engines in excess of 500,000 total horsepower during the First World War. Thereafter, MAN was particularly noted for geared diesel engines, and provided the motive power for the German pocket battleships, Deutschland and Admiral Graf Spee. Smith, A Short History of Marine Engineering, 337, and McNeil, ed., Encyclopaedia of the History of Technology, 324.
} 
140 had Doxford engines and 101 had Dutch Werkspoor engines. ${ }^{58}$

That Doxford continued to compete afterbeing denuded of its liquid assets during the largely depressed interwar period against its larger continental competitors was laudable. Its championship of the opposed piston slow speed marine crosshead main diesel engine had overcome a great deal of inbuilt prejudices of British tramp ship owners. Unsurprisingly, given the firm's continuing problems with liquidity, development work on Doxford main engines had continued intermittently. ${ }^{59}$ Doxford also attempted to enter the market for small-bore engines for the low power and industrial markets, but entry into the latter was unsuccessful. ${ }^{60}$

During the Second World War Doxford completed a large series of very successful standard ships of 9,000 dwt and 450ft in length, which continued in production throughout the war. By October 1945 they had built seventy-eight, with an aggregate tonnage of 535,000 gross tons. Of these ships, seventy-three Doxford engines had been installed and a further thirty-five engines delivered to other shipbuilders. ${ }^{61}$

\section{NPL and the shipbuilding industry}

Before 1939 only the NPL at Teddington and individual shipbuilding firms continued to carry out research. The industry, to a large extent, relied on NPL to give estimates, through tank testing and calculations thereon, of power requirements for a new ship. Such estimates gave the builder knowledge of the speed achieved with a given size of engine. Primarily, the NPL Ship Division was concerned with the underwater shape or form of the ship and its propeller. ${ }^{62}$ Only when a design from a shipbuilder or ship owner got through initial screening and no drastic modifications were needed would a model be produced for experimental purposes, and which corresponded to the exact underwater form of the ship with about six inches freeboard. In 1938, the Port Glasgow shipbuilder, Sir James Lithgow (1883-1952) underwrote the construction of a low-pressure water tunnel at the NPL to test propeller design for cavitation. ${ }^{63}$

\footnotetext{
58 Werkspoor-Nederlandse Fabriek van Werktuigen en Spoorwegmaterieel (Dutch Machine and Railway Equipment Works), was founded in Amsterdam in 1827. They merged with Stork in 1954 and their marine diesels became known as Stork Werkspoor. For the early years, see, T.O. Lisle, "Six Years Development of the Werkspoor Marine Diesel Engine," Journal of American Society for Naval Engineers 28:3 (1917), 579-584.

59 W.H.Purdie, "Thirty Years Development of Opposed Piston Propelling Machinery," Proceedings of the Institution of Mechanical Engineers, 162 (1951), 446-64. In 1924 Doxford pioneered a threecylinder, single acting engine and in the next four years these engines were fitted into tramp ships.

60 Griffiths, "British Marine Industry and the Diesel Engine," 21.

61 Richardson, William Doxford \& Sons Ltd., 189; Shipping World, 9 January 1946 gives the figure of eighty ships.

${ }^{62}$ It was often necessary for NPL to design a propeller to suit a certain engine power and revolutions. This was mostly achieved by means of standard data using the effective horsepower obtained from resistance experiments as a basis, NPL designed and manufactured model propellers made of white bronze, being exact scaled replicas of those to be fitted in ship.

63 In such a tunnel, water is driven around a closed vertical circuit by means of an impeller in the
} 
The road to a Research Association

From late 1939, onwards, the British shipbuilding industry had quickly come under government control. Responsibility for naval construction, particularly the production of escort vessels remained with the Admiralty, who in turn retained overall responsibility for the industry. In the early stages of the war, the legacy of the interwar period of an industry starved of investment soon became apparent. This was confirmed during 1942 when the industry was subjected to two governmentbacked investigative reports, completed in July and September respectively. Both were highly critical and suggested a raft of changes and improvements, including a widespread extension of electric arc welding and more modern plant and equipment to facilitate increased production. ${ }^{64}$

Subsequently, most of the finance needed for this came from the Admiralty in the form of grants, and a Shipyard Development Committee under the chairmanship of Sir James Lithgow was set up to supervise the process of re-equipment, which it quickly achieved ${ }^{65}$ This example of successful government and industry cooperation laid the groundwork for further co-operation to improve the industry's prospects in the post-war period.

Although this was important, it was not enough to prompt the industry to set up a research association. Notwithstanding the withering experience of the mainly depressed interwar period; the major catalyst that exercised the minds of the principals of the major firms in the forum of the industry's trade association, the Shipbuilding Conference from 1940 onwards, was the spectre of international competition in the post-war period. ${ }^{66}$

Prior to 1940, although the British shipbuilding industry and the British mercantile marine were the largest in the world, increasing international competition, especially on price had begun to impact negatively on their competitiveness. In shipbuilding and in shipping, Germany, Sweden and Japan had become significant competitors accounting in total for over one-third of world tonnage launched by the end of the interwar period from a base of 12 percent in 1924. In contrast, British shipbuilding's share of world launches had declined from a peak of 64 percent in 1924 to 34 percent in 1938, this from an industry which in 1913 had launched more tonnage than the rest of the world combined and four times more than its nearest

lower limb through the test section in the upper limb.

64 Labour in Naval and Mercantile Shipyards (Barlow Report), July 1942, TNA ADM 1/11892; Report to the Machine Tool Controller on the Equipment of Shipyards and Marine Engineering Establishments (Bentham Report), September 1942 , TNA BT 28/319

65 C. Barnett, The Audit of War. The Illusion and Reality of Britain as a Great Nation (London: Pan, 1996), 119, Barnett termed this "a remarkable feat of re-equipment in the middle of a world war." See also, Lewis Johnman and Hugh Murphy, British Shipbuilding and the State since 1918: a political economy of decline, (Exeter: University of Exeter Press, 2002), 80-83.

66 For this, see, H. Murphy, "No Longer competitive with Continental Shipbuilders: British Shipbuilding and International Competition, 1939-1960," International Journal of Maritime History 25:2 (2013), 35-60. 
rival, Germany. ${ }^{67}$

Given this decline, the fear from some of the more far sighted members of the Shipbuilding Conference was that as foreign shipyards eventually re-equipped in the postwar period and if demand persisted, then competition would be further fuelled by the widespread adoption of capital intensive means of production with bought in technology and the use of more flexible labour forces. Indeed, British shipbuilders were aware of the lessons of the United States Emergency War Shipbuilding Program. There, concepts of mass production prevalent in other industries such as pre-fabrication, standardization and flow line production methods had been borrowed. Allied

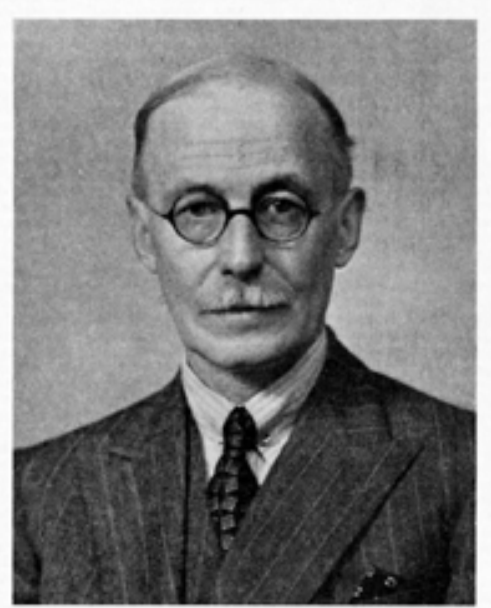

Sir Maurice Denny to the widespread use of electric arc welding, this had resulted in ships being produced much quicker than hitherto, but at an initially greater cost. ${ }^{68}$

By 1943 therefore, British shipbuilding was, in terms of applied and coordinated research and production methods, atomistic. Shipbuilding is essentially an assembly industry with the cost of the hull comprising little over one-third of the cost of the completed ship. Accordingly, the industry, with the partial exception of the larger firms which combined marine engine-building, pushing the percentage of in-house manufacturing up, was to varying degrees heavily reliant on sub-contractors for main propulsion and auxiliary equipment. ${ }^{69}$ Moreover, the shipbuilding industry could to an extent rely on the classification societies and on other research bodies such as the British Welding Research Association and the British Iron and Steel Research Association to promulgate research by default which was advantageous to it. It could also to an extent rely on large subcontractors such as steering gear and pump manufacturers to finance their own research and development costs, although these costs would eventually filter through in higher prices for finished manufactures. Additionally, the results and stimulation of research applicable to shipbuilding had long been promulgated by professional bodies ${ }^{70}$

\footnotetext{
67 Unless otherwise stated all tonnage, figures are taken from Lloyd's Register of Shipping Annual Registers.

68 These factors are considered in greater depth in Lewis Johnman and Hugh Murphy, "The British Merchant Shipping Mission in the United States and British Merchant Shipbuilding in the Second World War," The Northern Mariner/Le marin du nord 12: 3, July 2002, 1-15. See also, Johnman and Murphy, British Shipbuilding and the State, 84-87.
} 
Throughout the war the DSIR had continued to part-sponsor numerous industrial research associations and by 1943, in large part because of the advocacy of the Clyde shipbuilder and marine engineer, Sir Maurice Denny Bt. (1886-1955), the Shipbuilding Conference had been considering setting up a research association for the industry. Denny, when he took over as chairman of the Shipbuilding Conference in 1940 saw it as basically a "loose price protective organisation," 71 but was determined to change its focus. Underpinning the establishment of BSRA and PAMETRADA, Denny noted: "It cannot be denied that since the last war most of the major developments in ships, and especially in their propelling machinery, have been due to foreign vigilance in scientific and technical development." $72 \mathrm{He}$ further acknowledged that this was an issue that now had to be faced. ${ }^{73}$ Crucially, the two nascent associations were intended to complement each other. BSRA would be responsible to, and primarily financed by the shipbuilders through the Shipbuilding Conference. Several of the larger mixed naval and mercantile shipbuilders in the Conference, such as John Brown at Clydebank, Vickers Armstrong at Barrow, and Hawthorn Leslie on the Tyne were also turbine manufacturers and would also be members of PAMETRADA, which would be financed primarily by its member firms. In a sense the two bodies would be under a form of common ownership and ultimately their terms of reference were carefully arranged as not to overlap. BSRA would cover the entire field of shipbuilding together with such aspects of marine engineering as main marine diesel engines, not covered by PAMETRADA. ${ }^{74}$

Denny expressed in a memorandum to his fellow shipbuilders what he saw as the fundamental problem to confront the industry in the postwar world, improved production methods, whose take up would eventually result in reduced costs relative to competitors. ${ }^{75}$ Denny's emphasis on reduction of costs, sooner rather than later, necessarily envisaged a research association promulgated on a practical rather than on a largely theoretical approach to research. His emphasis on practicality mirrored that of an industry where the cult of the "practical man," a man hewn from the rock of applied experience rather than by theoretical teaching, held sway. Earlier in 1942, the Controller of Merchant Shipbuilding at the Admiralty, Sir James Lithgow reinforced this view, noting in connexion with the establishment of a research association, that: "the shipbuilding industry is ripe for any forward move of this kind, provided it is planned on practical lines and is working under

\footnotetext{
71 A. Slaven, "Sir Maurice E. Denny," Dictionary of Scottish Business Biography, (Aberdeen: Aberdeen University Press, 1998), 213.

72 Report by Policy Committee to Executive Board Meeting of the Shipbuilding Conference, 13 July 1943, Research policy. Memorandum by Sir Maurice Denny, March 1943, NMM SRNA 4.

73 Ibid.

74 As was the case with the shipbuilder's organisations where the same people served on committees of the Shipbuilding Conference and Shipbuilding Employers Association, there was similar cross membership between BSRA and PAMETRADA.

75 Shipbuilding Conference, Shorthand Notes of Policy Committee Meeting, 6 May 1943, Report of the Policy Committee, 13 July 1943, and Research Policy Memorandum by Sir Maurice Denny, March 1943, NMM SRNA 7.
} 
the control of practical people." 76

Lithgow also enquired if the government would make up its mind on whether to support the proposed organization morally and financially. His sentiments on practicality were echoed by the Burntisland shipbuilder, Sir Amos Ayre, (18851952) who noted that: "the people who run these things must have experience in, and the responsibility for, the design and production of ships, we have far too many naval architects who are unable to build ships." 77

Underpinning Denny's case was the essential need to improve and then maintain the industry's competitive ability relative to international competition by advancing a policy of applied research to gain a technological lead. This, however, implied a sea-change in attitude from shipbuilders on the supply side, but particularly from British ship-owners whose design needs largely determined demand. Any attempt at homogeneity of product, given the nature of bespoke construction for mainly British owners, militated against industry-wide standardization. On the supply side, cheaper hulls, for example, always dependent on the price of steel, required a more efficient means of production than hitherto. This implied an added emphasis on production planning, a concept somewhat alien to the industry as it implied an increased element of higher management control over work organization, rather than leaving it to industry-experienced foremen and casualized squads of workers, a system still extant from the nineteenth century. Crucially, any advancement of research and the realization of research outcomes required a greater level of co-operation between shipbuilders and ship-owners, two distinct groups whose respective interests in economic terms fundamentally diverged rather than coalesced.

Given the myriad shortcomings of the industry exposed by official government reports, the initial impetus to set up some form of co-operative research association had been set in train outside it. By August 1942, Sir Charles Galton Darwin (18871962), then director of the NPL had circulated a paper on ship research to shipowners, shipbuilders, the Ministry of War Transport and the Institute of Naval Architects. ${ }^{78}$ Darwin obviously had the ear of government, and by October, Sir Cyril Hurcomb (1883-1975) of the Ministry of War Transport had requested shipowners and shipbuilders to consider, in line with adjusting the national economy to peacetime conditions, a scheme of joint research. Clearly, by this juncture, the government felt that co-operation in a more ordered system of planning between ship-owners and shipbuilders would result in a more stable shipbuilding industry in terms of employment than hitherto. By December, this had been agreed in principle, although no consideration had been given to the possible extent and the nature of co-operation. Thereafter, Sir Maurice Denny was entrusted by the Shipbuilding Conference to prepare a memorandum about research for approval

\footnotetext{
76 Letter from Sir James Lithgow to Sir Julian Foley, 19 June 1942, NMM SRNA 4, R2/A.

77 Letter from Sir Amos Ayre to Sir Julian Foley, 17 July 1942, ibid.

78 Report of AGM of the Shipbuilding Conference, 3 February 1943, NMM SRNA 7.
} 
by first, the Conference's Policy Committee, and then by the industry. ${ }^{79}$

Denny noted in terms of research on hulls, that outside the hydrodynamic field, the scope was not conspicuous, except for production methods: "the importance of and urgency of which can hardly be exaggerated." This, to some extent, mirrored Darwin's earlier memorandum which commented that yard layout might be the subject of research, but went further, as Denny envisaged: "A systematic study of layouts, processes and plants, the adoption of the gains offered by the most recent technical progress and above all the formation of a common front in the determination to make necessary changes." ${ }^{80}$ This would, if implemented, lead to greater efficiency, but its passage was by no means guaranteed in what remained an innately conservative industry.

Accordingly, by the time Denny's thoughts became the subject of discussion at several meetings of the Shipbuilding Conference policy committee, it had become clear that his reference to production methods research was to be expunged, and so it transpired.$^{81}$ Thus, before the formation of a research association, arguably what should have been its most important research function, the theoretical underpinning, applied testing and eventual promulgation of modern yard layouts, plant and equipment and production methods was excised.

\section{British Shipbuilding Research Association}

In consultation with the DSIR, which would part-fund it, BSRA was finally set up in April 1944 along the lines of other research associations, with responsibility for matters of general policy, management, organization and finance resting on the Shipbuilding Conference, which would part-fund it from its General and Administrative levy raised from its seventy-six member firms. BSRA was the first such research association formed by a shipbuilding nation. Its objects were: "to establish for the industry a foremost place in scientific shipbuilding', and to provide the industry in ready form an up-to-date and continuous picture of scientific developments in shipbuilding throughout the world, and to seek close co-operation with other research associations and ensure speedy publication of results." ${ }^{2}$ BSRAs governing body was termed the Shipbuilding Research Council (SRC) and consisted of the major players in the industry on an elected basis, but also contained representatives of the DSIR. Directly responsible to the SRC was the research board of BSRA, which in addition to shipbuilders contained members of National Association of Marine Engineers (NAME), the Dry Dock Owners and

\footnotetext{
79 Denny Memorandum, March 1943, Shipbuilding Conference Executive Committee Reports and Papers. NMM SRNA 7.

80 Ibid.

81 Research BSRA, memo from RDB to Alexander Belch, 13 July 1944, NMM SRNA 4 P11/3.

82 Wilfrid Ayre, "The British Shipbuilding Research Association," Transactions of the Institution of Naval Architects, 86 (1944) paper No.3. Ayre was Chairman and Managing Director of the Burntisland Shipbuilding Company Ltd., Fife Scotland, and a member of the Research Board of BSRA.
} 
Repairers Central Council, the Admiralty, the General Council of British Shipping, classification societies and professional institutions. The research board, in turn, had responsibility for setting up research panels composed of experts in their chosen fields to investigate specific lines of inquiry ${ }^{83}$

By September 1944, Dr. S.L. Smith (1889-1959), formerly of the NPL, had been appointed director of research at BSRA and Dr. J.F.C. Conn (1903-1993) appointed as chief naval architect. Conn later became professor in that subject at the University of Glasgow. ${ }^{84}$ Smith's duties were to generally direct and supervise the research functions of the association, which had technical staff split into three sections: naval architecture, marine engineering, and intelligence (scientific and technical). Most of the technical grades were not shipbuilders but were marine engineers and naval architects recruited from various government scientific services. BSRA maintained a head office and staff in the former mid-Victorian home of the Earl of Donoughmore in the west end of London, near the headquarters of the Shipbuilding Conference.

Crucially, as a matter of policy, BSRA did not undertake expenditure on establishing a research station or laboratories. For the most part its research was undertaken on an extra mural basis, with experimental work being carried out under BSRA supervision in public laboratories, in the testing tanks of member firms, the NPL, other research associations and in universities, which gave it flexibility. ${ }^{85} \mathrm{In}$ short, BSRA policy was to provide extant ship and machinery designers with data and information enabling the production of better designs. ${ }^{86}$

Initial funding for BSRA was granted by the DSIR on a quinquennial basis with the precondition that the industry raised a certain amount of minimum income for it, and that its contributions would exceed those of the DSIR on an annual basis. From 1944 the industry, through the Shipbuilding Conference, had initially agreed to fund BSRA to the minimum sums of $£ 50,000$ for each of the first two years and $£ 80,000$ per annum for the remaining three years to 31 March 1949, a total expenditure of $£ 340,000$. Provided BSRA raised $£ 50,000$ the DSIR would contribute $£ 30,000$ and match every additional $£ 100$ up to a maximum of $£ 30,000$.

\footnotetext{
83 Ibid.

${ }^{84}$ John Elder Chair of Naval Architecture in 1957.

${ }^{85}$ For example, on ships structures, deflections on framed box girders were measured at Imperial College London, these were specially made for testing the effect of width of long deckhouses on stresses taken by girders. Launching tests were carried out at John Brown, Clydebank to investigate the question of initial forces on launching triggers and tests on greases based on petroleum products were carried out. Vibration experiments were carried out on wax models at the NPL. See, BSRA $4^{\mathrm{TH}}$ Report, 1 April 1948-31 March 1950.

86 Although this was the general policy of BSRA, where there was a special need for a particular piece of apparatus it was prepared to provide it. A good example was the acquisition from the Welding Research Council of a structures testing machine at Messrs Colvilles works at Glengarnock, Ayrshire, Scotland capable of applying lateral loading to full size components of ships structures, and by 1949 an additional machine capable of applying simultaneous axial and lateral loads was in the process of being built. DSIR Report, 1948-49, NMM SRNA 4 R2/B. The structures testing machine was operated under contract for BSRA by staff of Lloyd's Register.
} 
In fact, BSRA only raised enough income from the Shipbuilding Conference in each of the first four years to qualify for the minimum grant. ${ }^{87}$

However, by May 1949 in a continuing climate of national austerity, DSIR insisted that the industry fund BSRA to the extent of $£ 100,000$ per annum, and that for every complete $£ 100$ by which the grant exceeded $£ 100,000$, DSIR would match it up to a maximum of $£ 25,000$ per annum. ${ }^{88}$ Accordingly, for the financial year ending in March 1949 the Shipbuilding Conference agreed to fund BSRA to the sum of $£ 120,000$ rather than the $£ 80,000$ originally envisaged, aided by an increase in conference levy as the result of the volume of post-war liner reconversion work in member firms. Moreover, for the first two years of the next five-year funding cycle, the Shipbuilding Conference agreed to pay $£ 120,000$ per annum but thereafter $£ 100,000$ per annum for the remaining three years to March 1954. A position they justified by the difficulty of foreseeing future Conference income from levies on individual firms, which were determined by the level of demand for ships. By this stage, in line with the increased levels of funding, it had also been agreed that increased financial supervision within BSRA was desirable. ${ }^{89}$

Earlier in September 1945, the SRC had approved the first programme of research recommended by the research board. The latter formed four main committees and eleven sub-committees, and initial resources were concentrated on four main areas: hydrodynamics; ship structures; ship performance, and ships machinery. ${ }^{90}$ The establishment of BSRA and the level of support for it; was at least encouraging, but it remained to be seen how effective the association would be in the medium-to-long-term. Contemporaneously, the shipbuilding industry, through its member firms and associated marine engine-builders, had financed another research association, PAMETRADA, an extension of a relationship made by a limited number of shipbuilding and marine engine-building firms before the war with the only indigenous designer and manufacturer of large marine steam turbines, the Tyne based C.A. Parsons Co., Ltd., to develop marine turbines.

\section{PAMETRADA}

In 1943, the Admiralty had set up a committee to specifically investigate steam turbine machinery for warships. ${ }^{91}$ In addition to shipbuilding firms, certain land turbine firms were also represented on the committee. By early 1944, enough impetus towards the establishment of a marine turbine research association had been given by Sir Charles Craven (1884-1944) of Vickers Armstrong (Barrow and

\footnotetext{
87 AGM 23 February 1949, NMM SRNA 7, Shipbuilding Conference AGM Report Series.

88 Letter from DSIR to chairman of BSRA, 16 May 1949, NMM SRNA 4 R2/A.

89 AGM 23 February 1949,NMM SRNA 7, Shipbuilding Conference AGM Report Series.

90 Shipbuilding Research in Great Britain, Pamphlet issued by BSRA, January 1947, 10.

91 J.R. Parkinson, The Economics of Shipbuilding in the United Kingdom, (Cambridge: Cambridge University Press, 1960), 134.
} 
Walker on Tyne) and Philip Johnson (1887-1964) of Hawthorn Leslie (Tyne). ${ }^{92}$ Contemporaneously, the Admiralty had also urged the creation of PAMETRADA on two related fronts: a general dissatisfaction with the existing state of the British marine steam turbine engineering sector, most of whom were licensees of C.A. Parsons, a company who the Admiralty felt had fallen behind international competition, and second, the perceived supremacy of American naval steam turbine design prowess and manufacturing techniques during the war. Despite these reservations, the Admiralty backed the creation of PAMETRADA. The memorandum of agreement between the Admiralty and PAMETRADA contended that it was the former's intention "as far as possible to place a fair volume of work with the latter in each of the next few years," hardly a ringing endorsement. Although it had been anticipated that direct funding would come from the Admiralty, this did not in fact materialize as "Admiralty support" qualified PAMETRADA for DSIR grant in aid. ${ }^{93}$

The creation of PAMETRADA to an extent resolved a long-running problem of research and development in the smaller marine turbine firms in both the shipbuilding and marine engine building sectors who could not afford to support adequate research or design teams, but who still manufactured main engines under licence. ${ }^{94}$ Responsibility for PAMETRADA lay with a council chaired by Sir Philip Johnson, with the day-to-day running of the association from September 1944 under the direction of Dr. Thomas Walter Falconer Brown CBE, DSc (19011995) formerly of the Tyne shipbuilders and engineers, Hawthorn Leslie. ${ }^{95}$

PAMETRADA took over the design, research and development of marine steam turbines, but the clear emphasis was on blade-path design. Crucially, from the outset, the division between basic design in house in PAMETRADA, and detailed design and manufacture elsewhere by its member firms, which it had no control over, meant that PAMETRADA could not guarantee the performance of the designs. PAMETRADA also had no remit to inspect production, therefore supervision in standardising production in member firms was lacking, and likely to have far-reaching consequences. Ideally, research, design, and manufacture should have been closely integrated and under one roof. Moreover, the creation of PAMETRADA can also be interpreted as a defensive move by the shipbuilders

\footnotetext{
92 Clarke, Building Ships on the North East Coast, Vol., 2, 423.

93 Independent Committee of Inquiry into Shipbuilding Industry, Memorandum on Pametrada with Particular Reference to the Lack of Support from the Navy Department, circa July 1966, TNA BT $186 / 20$.

94 Generally, licensor's provide licencees with complete designs including working tolerances. Licence agreements normally prohibit the licensee from altering the licensor's design without prior approval and give the licensor the right to inspect production.

95 A Scotsman, Brown had studied engineering at the University of Glasgow where he gained a DSc degree. He served an apprenticeship at Alexander Stephen at Linthouse, and later moved to Hawthorn Leslie on the Tyne - one of the big five shipbuilding turbine manufactures. (The others were John Brown, Cammell Laird, Harland \& Wolff and Vickers.) Brown was awarded a CBE in the Queen's Birthday Honours List of 1958.
} 
as they were more than aware of Admiralty dissatisfaction with the industry's performance in the marine turbine field, and its likely greater engagement with the land turbine firms.

(To be continued.) 